\title{
DIREITO AMBIENTAL E DESENVOLVIMENTO SUSTENTÁVEL: UMA ANÁLISE DA JUDICIALIZAÇÃO DAS RELAÇÕES SOCIAIS
}

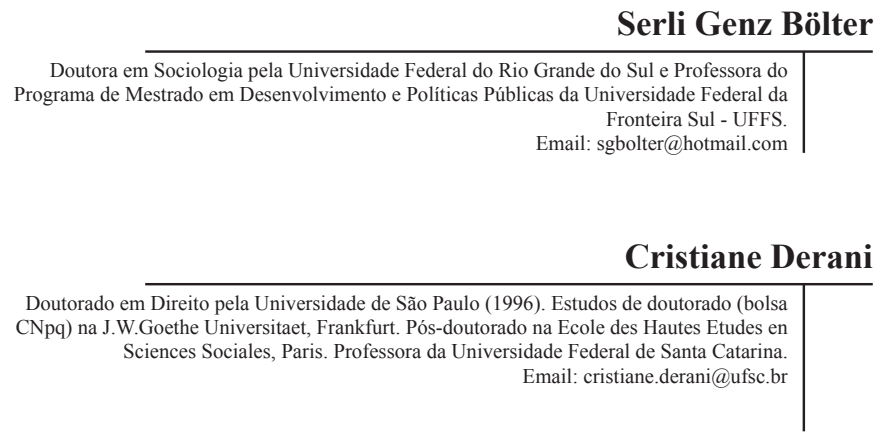

\section{RESUMO}

O presente artigo trata da judicialização das relações sociais, especificamente sobre a judicialização dos conflitos ambientais em sua relação com os conceitos de desenvolvimento sustentável e direitos da natureza. A análise realizada toma como referência decisões proferidas pelo Supremo Tribunal Federal do Brasil, no período posterior à Constituição Federal de 1988. São estudadas três decisões: a primeira, que trata da implementação do Código Florestal brasileiro de 2001, julgada em 2005; a segunda, uma decisão sobre a importação de pneus recicláveis, julgada em 2009; e, a terceira, a decisão sobre uma lei do estado do Ceará que trata da vaquejada, julgada em 2016. Em todas, busca-se identificar as alterações que as decisões demonstram no viés do desenvolvimento e da sustentabilidade. Argumentase que a crise socioambiental exige a construção de um novo paradigma no tratamento das questões ambientais no qual estejam presentes as noções de desenvolvimento sustentável e da natureza como detentora de direitos.

Palavras-chaves: judicialização; desenvolvimento; sustentabilidade; direitos da natureza. 


\title{
ENVIRONMENTAL LAW AND SUSTAINABLE DEVELOPMENT: AN
} ANALYSIS FROM JUDICIALIZATION OF SOCIAL RELATIONS

\begin{abstract}
This article treat about the judicialization of social relations, specifically on the judicialization of environmental conflicts and the treatment of the concepts of sustainable development and the relation with the rights of nature. The analysis carried out takes as reference decisions issued by the Federal Supreme Court of Brazil in the period after the Federal Constitution of 1988. Three decisions will be taken with reference: the first one treat of the implementation of the Brazilian Forest Code of 2001, judged in 2005; the second, a decision on the importation of recyclable tires judged in 2009; and the third, the decision on a Law of the State of Ceará on the vaquejada, judged in 2016. In all attempts to identify the changes that the decisions demonstrate in the treatment bias from a development and sustainability perspective. It is argued that the socio-environmental crisis requires the construction of a new paradigm in the treatment of environmental issues in which the notions of sustainable development and nature as a right are present
\end{abstract}

Keywords: judicialization; development; sustainability; rights of nature. 


\section{INTRODUÇÃO}

Vive-se um tempo marcado pela complexidade. Um tempo de mudanças, de crises e de grandes desafios. As promessas da modernidade foram só promessas. As expectativas da pós-modernidade são desalentadoras. $\mathrm{O}$ que há frente às incertezas contemporâneas é a aposta na diversidade, na pluralidade e na necessidade de novos parâmetros para a construção de respostas. Enquanto o novo não se define, buscam-se respostas em velhos moldes e ensaiam-se tentativas de novos contornos, de novos valores e, portanto, de novas perspectivas nos modelos que nos cercam.

O estudo do Direito Ambiental em um Estado de Direito é, em certa medida, esse ensaio por respostas. O que se tem no campo do Direito Ambiental no Brasil é o resultado de um processo de redemocratização do Estado brasileiro no contexto da América Latina: limitado, copiado, formal, dogmático e, acima de tudo, vinculado às velhas promessas de efetivação dos direitos. Promessas de que o direito, a partir do formalizado, poderá ser garantido, ser efetivado. É em decorrência da complexidade dessa matéria, pelas implicações que representa para a organização da vida em sociedade, que se opta em analisá-la sob a perspectiva do desenvolvimento sustentável, ou seja, sobre como se estabelece a relação entre desenvolvimento sustentável e o Direito Ambiental posterior à Constituição de 1988, no Brasil.

Os processos de judicialização dos conflitos ambientais têm evidenciado uma intervenção do Poder Judiciário nas relações sociais. Neste trabalho, busca-se identificar em que medida tais mecanismos de implementação das normas jurídicas permitem avanços ou retrocessos na perspectiva conceitual referente ao campo do Direito Ambiental. É, também, um dos objetivos do presente estudo entender quais são os sujeitos que podem aparecer como propulsores ou mediadores do fenômeno da judicialização.

Como procedimento de pesquisa, foi realizada uma busca jurisprudencial no site do Supremo Tribunal Federal com três filtros: terminológico (desenvolvimento sustentável), disponibilidade da informação (acórdão na íntegra) e temporal (posterior a 1988). Foram encontrados 43 acórdãos na íntegra, com o termo 'desenvolvimento sustentável'. O propósito da análise é comprovar o fenômeno da judicialização dos conflitos ambientais e, ao mesmo tempo, identificar 
o tratamento do desenvolvimento sustentável e a relação com o direito da natureza, o que exige um estudo detalhado das decisões selecionadas. Para dar conta do segundo objetivo, justifica-se a escolha de somente três decisões que temporalmente evidenciam diferentes entendimentos dessa temática pela Suprema Corte no Brasil: a de 2005, a de 2009 e a de 2016. Busca-se identificar a dimensão conceitual do texto normativo na aplicação em caso concreto.

Considerando-se a crise socioambiental atual, apontamse algumas alternativas que precisam ser construídas no campo do Direito Ambiental e que se encontram em sintonia com a realidade latino-americana. É imprescindível, portanto, tematizar a relação seres humanos e natureza, o que remete à necessidade da construção de um novo paradigma nesse campo de estudo. Tal paradigma contém pelo menos dois desafios aparentemente contraditórios: primeiro, considerar historicamente a relação entre seres humanos e natureza, identificando as perspectivas tanto do desenvolvimento quanto da preservação da natureza; e, segundo, o reconhecimento de que a natureza pode ser detentora de direitos. Aproximar-se desse debate, problematizando os termos através do quais ele está colocado a partir da análise de situações empíricas, nas decisões das cortes superiores, é o propósito do presente trabalho.

\section{A CONSTRUÇÃO JURÍDICA DE NOVOS PARADIGMAS PARA O DIREITO AMBIENTAL NO ESTADO DEMOCRÁTICO DE DIREITO NO BRASIL E AS IMPLICAÇÕES PARA O DESENVOLVIMENTO SUSTENTÁVEL}

Para a análise da relação entre Direito Ambiental e desenvolvimento sustentável, especificamente neste artigo, parte-se do estudo do fenômeno da judicialização dos conflitos sociais. Entendese adequado fazer uma leitura inicial de como se positivam as questões ambientais e como se define constitucionalmente desenvolvimento sustentável no Brasil pós-Constituição Federal de 1988, especialmente em relação aos procedimentos e às estratégias para a efetivação dos direitos que são construídos nessa área. Reconhece-se que, no campo da positivação dos direitos, o período posterior à Constituição Federal de 1988 é marcado pela ampliação formal dos direitos. O texto constitucional é resultado de um período de disputas sociais e indica a retomada da redemocratização das relações políticas e, consequentemente, da garantia dos direitos se não 
no campo da realização, pelo menos no campo da formalização.

A Constituição Federal permitiu avanços significativos na perspectiva de positivação das normas jurídicas ambientais ena normatização sobre desenvolvimento. $\mathrm{O}$ texto constitucional é expressamente um texto garantidor de direitos, em uma perspectiva de proteção e preservação ambiental. Dois elementos indicam esses avanços: primeiro, a garantia de um meio ambiente ecologicamente equilibrado, assegurado para as presentes e as futuras gerações (art.225 CF/88); e, segundo, o princípio de que o desenvolvimento deve ser entendido sob a ótica do desenvolvimento sustentável e da proteção ao meio ambiente (art. 170 da CF/88). Esses fundamentos permitem afirmar que os moldes do Direito Ambiental no Brasil têm interpretações para além da velha perspectiva antropocêntrica da relação homem e natureza. Exigem, além disso, um modelo de perspectiva econômica que supere os contornos reducionistas do desenvolvimento restrito ao crescimento econômico.

Os dispositivos constitucionais apontados são dois fundamentossignificativos queprecisam ser desenvolvidos conceitualmente, porque exigem perspectivas diferenciadas para a criação e a efetivação de normas jurídicas. Eles incidem diretamente na implementação de políticas que garantam a consolidação de um novo olhar sobre o Direito Ambiental brasileiro e a modelagem de desenvolvimento a ser construído.

O Direito Ambiental brasileiro, no entanto, ainda é produzido na perspectiva de um meio ambiente equilibrado, com marcos legais fortemente influenciados por um modelo do uso racional dos bens naturais. Há a prevalência de uma visão que separa o ser humano da natureza e que reafirma uma visão de natureza como recurso natural, uma relação utilitarista na qual o ser humano se apropria desses bens e os transforma em recursos para a produção econômica. Aqui, a visão prevalecente é a de que a "natureza é recurso (matéria a ser apropriada) natural, e o homem - ser humano -, sujeito apartado do objeto a ser apropriado, não é mais natureza. Sujeito e objeto vivem dois mundos: o mundo social e mundo natural." (DERANI, 2008, p. 52) Essa perspectiva, no entanto, não é a apresentada, por exemplo, na Lei 6.938/81, no art.3․ inciso I: "conjunto de condições, leis, influências de ordem física, química e biológica, que permite, abriga e rege a vida em todas as suas formas", que já assinala para uma visão mais ampliada do Direito Ambiental.

O uso do artigo de lei infraconstitucional acima serve para exemplificar a existência de dispositivos constitucionais, já citados, e 
infraconstitucionais, que evidenciam o predomínio da visão antropocêntrica na normatização do Direito Ambiental brasileiro, convivendo com inúmeros dispositivos e conceitos que apontam para um novo paradigma do Direito Ambiental: uma visão que procura modificar a relação ser humano/natureza. É essa visão que começa a reconhecer os direitos da natureza. Apresenta-se a dimensão de um Direito Ambiental que é elevado a uma classificação de direito fundamental da pessoa humana, baseado em uma concepção material e não apenas formal (DERANI, 1997). É uma concepção que permite apontar algumas resistências em relação ao colapso que se vislumbra, pelo uso e pela apropriação sem controle dos 'bens ambientais'.

Um desafio para essa mudança de perspectiva teórica é o envolvimento de todos os sujeitos e as instituições responsáveis pela produção da ordem jurídica em um Estado Democrático de Direito e, além disso, responsáveis pela efetivação desses dispositivos. Uma perspectiva que vá além do antropocentrismo pode ser entendida como a forma de estabelecer as regras para a relação ser humano e natureza. Exige sujeitos que reconheçam a condição da existência do direito da natureza. É um desafio especialmente pela existência dessa dualidade nos dispositivos constitucionais e infraconstitucionais. Ou seja, estudar novos paradigmas exige a apreensão de que produzir o Direito é modificar a perspectiva que fundamenta as normas e os moldes de sua produção e implementação. O que se coloca como questão é, justamente, como a judicialização dos conflitos sociais pode constituir uma das estratégias para ampliar a concepção do Direito Ambiental no Brasil e, especialmente, consolidar uma perspectiva de desenvolvimento sustentável como condição para uma relação diferenciada entre seres humanos e natureza.

O fenômeno da judicialização das relações sociais evidencia um tempo em que se reconhece que o Estado é demandado para além do exercício de suas atribuições clássicas de legislar, fiscalizar e assegurar o cumprimento das normas. Há nas produções normativas a necessidade de identificar uma dimensão de princípios, de atribuição de sentidos e de definição de fundamentos em sua aplicação, que são reveladores de um tempo que aponta para a complexidade das relações sociais e, mais do que isso, de um tempo em que os significados das normas jurídicas precisam dar conta de uma sociedade que exige uma nova atuação do Estado. Um tempo em que o Estado jardineiro (BITTAR, 2004), que somente atua na superfície das relações, não consegue silenciar demandas 
sociais cada vez mais complexas. É nessa perspectiva que as prescrições normativas sobre o Direito Ambiental devem ser analisadas e, por isso, a análise deve considerar as normas sobre desenvolvimento sustentável em sua relação íntima com o Direito Ambiental.

Para justificar essa perspectiva, deve-se primeiro caracterizar de que tempo está- se tratando. Para Bittar (2009, p. 104), a pós-modernidade designa "um contexto sócio-histórico particular, marcado pela transição, [que] não gera unanimidades, e seu uso não somente é contestado como também está associado a diversas reações ou a concepções divergentes". Ressalta o autor que,

mesmo entre aqueles que aceitam o uso do termo para designar um estado atual de coisas, um processo de modificações que se projeta sobre as diversas dimensões da experiência contemporânea de mundo (valores, hábitos, ações grupais, necessidades coletivas, concepções, regras sociais, modos de organização institucional), não há sequer unanimidade na determinação da data que seria um marco para o início desse processo (BITTAR, 2009, p. 105).

A pós-modernidade está relacionada a um período de transição paradigmática, ao reconhecimento de uma crise dos valores, a um período de incertezas e de ausência de respostas aos problemas que surgem cotidianamente em uma sociedade que está em crise (SANTOS, 2002). Instala-se um tempo em que as respostas que a modernidade oferecia já não são suficientes, porém, sem existir novas respostas. É um tempo, no qual

“os sentimentos modernistas podem ter sido solapados, desconstruídos, superados ou ultrapassados, mas há pouca certeza quanto à ocorrência ou ao significado dos sistemas de pensamento que possam tê-los substituído. Essa incerteza torna peculiarmente difícil avaliar, interpretar e explicar a mudança que todos concordam ter ocorrido" (HARVEY, 2001, p 47).

Para a reflexão proposta neste artigo, da adoção de uma perspectiva de direitos da natureza para a leitura do Direito Ambiental no Brasil e especialmente da necessidade de uma concepção de desenvolvimento sustentável como a possibilidade autorizada no sistema jurídico atual, entende-se adequada a identificação de um tempo pós-moderno, pois permite justificar a necessidade de novas respostas aos problemas da 
crise e dos efeitos danosos que o uso sem controle e uma perspectiva de apropriação dos bens naturais têm gerado. $\operatorname{Bittar}(2009$, p. 176) afirma que "a primeira percepção do advento da pós-modernidade e de sua projeção no âmbito jurídico é o de crise" E continua: "adveio a crise do próprio Estado" (2009, p. 177). Essa crise é, sobretudo, uma crise estrutural, na qual

os conflitos deixam de ter proporção e a perspectiva de serem conflitos individuais, e passam a se tornar conflitos conjunturais, coletivos, associativos, difusos, transindividuais, motivando o colapso das formas tradicionais de se atenderem a demandas para as quais somente se conheciam mecanismos típicos do estado liberal, estruturado sobre as categorias do individual e do burguês (BITTAR, 2009, p.178).

Para Bittar (2009, p.179-180) "concebeu-se, neste sentido, uma experiência de um Estado legalista, que se movimenta a partir de uma imensa miríade de textos normativos, atos burocráticos, expedientes dispendiosos, mas que, vivenciando a crise contemporânea, é incapaz de conter delitos os mais banais, ou mesmo de dar efetividade a normas de importância social reconhecida". Ou seja, além de modificar os fundamentos do Direito Ambiental a partir de princípios e conceitos que podem atacar, de forma central, os desafios da sociedade contemporânea, a adoção de uma concepção de pós-modernidade permite enfrentar a questão sobre a falta de eficácia do Direito Ambiental na relação com o desenvolvimento sustentável. Não faltam dispositivos normativos, não faltam fundamentos teóricos que sustentam uma nova perspectiva do Direito Ambiental; faltam respostas eficazes, faltam respostas que asseguram os direitos. Falta a percepção de que é urgente uma alteração das relações com a natureza como condição, inclusive, de sobrevivência de todos os seres humanos. Não é objetivo, aqui, resgatar todas as críticas sobre os processos de implementação dos modelos de Estado na América Latina,- pois essa reflexão colocaria em questão, inclusive, quais são os fundamentos das relações sociais, políticas e econômicas que sustentam esse pacto social, - ou mesmo questionar se existem essas relações pactuadas. $\mathrm{O}$ que se pretende é avançar em dois aspectos relacionados com o Direito Ambiental: desenvolvimento sustentável e a relação seres humanos e natureza.

Sobre as relações entre ser humano e a natureza, podese afirmar que as respostas, sob a perspectiva de uma sociedade de risco (BECK, 2010), já não são suficientes, pois a reparação e a prevenção, em algumas situações, são impossíveis. Aqui se pode usar a catástrofe 
ocorrida em Mariana (MG) como exemplo. Reconhece-se a existência de dispositivos normativos que podem responsabilizar os sujeitos envolvidos nos danos à natureza. O desafio, porém, é desenvolver políticas públicas que sejam alicerçadas em princípios de novas perspectivas de desenvolvimento e de estabelecimento de novas relações com a natureza.

Uma possibilidade para a análise do desenvolvimento é o de identificar a sustentabilidade com o cuidado na relação entre os seres humanos e a natureza. Nessa perspectiva, um conceito de desenvolvimento que pode auxiliar é o que permite identificar em que medida índices de desenvolvimento estão relacionados aos índices de desenvolvimento humano (SEN, 2010). Amartya Sen (2010, p. 22) afirma que: "[v]ivemos um mundo de opulência sem precedentes, mas também de privação e opressão extraordinárias. $\mathrm{O}$ desenvolvimento consiste na eliminação de privações de liberdade que limitam as escolhas e as oportunidades das pessoas de exercer ponderadamente sua condição de cidadão". O autor enfatiza que a ideia de desenvolvimento precisa estar relacionada com uma melhora de vida e indica que esta está intimamente relacionada ao aumento da liberdade. Tratar do desenvolvimento exige considerar a liberdade como um valor.

Bittar (2004) afirma sobre um tempo de pós-modernidade, ainda caracterizado pela existência de um Estado moderno, porém, complexo, em que a liberdade é um valor imprescindível. Boaventura (2016) indica, também, a intensificação de modelos nos quais a participação é emancipatória. Desenvolver é, portanto, aumento de liberdades, aumento da expressão da pluralidade, da diversidade e, especialmente, indicador de aumento de participação democrática, eficaz e de ingerência nos rumos dos modelos de políticas públicas. Entende-se que essa perspectiva exige um modelo de relações sustentáveis, de planejamento de regras nas quais a natureza seja relevante para essa melhora da qualidade dos indicadores de desenvolvimento humano: um ambiente saudável é condição para a melhora da qualidade de vida.

Quando Sen(2010) trata do desenvolvimento, afirma a necessidade de se considerar uma grande quantidade de variáveis: renda, educação, saúde, liberdade, bens, empoderamento das mulheres, transparência dos gestores, indicadores que apontam para um conceito de desenvolvimento como liberdade. Para a construção dessa perspectiva teórica, o autor aponta algumas limitações dos modelos de desenvolvimento baseados no tradicional "crescer para dividir". O autor denuncia esse modelo de 
distorções absurdas quando, usando como exemplo os Estados Unidos, de longe a nação mais rica do mundo, mostra que um homem negro americano tem uma expectativa de vida inferior a um homem chinês, ou costarriquenho, ou mesmo um habitante do estado de Kerala, na Índia (SEN, 2010). A riqueza não é partilhada por todos da mesma forma, quando as liberdades não são asseguradas. $\mathrm{O}$ desenvolvimento que tem como base meramente o desenvolvimento econômico pode não refletir em melhorias de condições de vida para todas as pessoas, o que leva ao questionamento: para que serve? (SEN, 2010). O modelo de desenvolvimento precisa considerar, portanto, melhorias na qualidade de vida. Entende-se que um dos indicadores de qualidade de vida está relacionado a um modelo de desenvolvimento sustentável em um ambiente saudável, com renda, moradia, saúde e liberdades.

A ênfase em um desenvolvimento com liberdade apresentada por Sen (2010) considera cinco grandes eixos, que salientam a dimensão da liberdade nas democracias modernas e que devem ser asseguradas para a garantia de uma perspectiva de desenvolvimento sustentável: 1) Liberdades políticas: - Incluem os direitos civis relacionados à liberdade de escolha por parte das pessoas sobre quem deve governar e por quê, além dos direitos relacionados à fiscalização e à crítica aos governantes por meio de uma imprensa livre; 2) Facilidades econômicas: - Oportunidades para as pessoas poderem utilizar recursos econômicos para o consumo, a produção ou a troca. $\mathrm{O}$ mercado tem um valor fundamental, pois permite a livre circulação de pessoas e produtos na economia, dimensões que devem estar vinculadas a princípios da sustentabilidade, pois a perspectiva teórica aponta para índices de desenvolvimento humano; 3) Oportunidades sociais: - Manutenção dos serviços de saúde, educação, segurança, lazer, que permite ao indivíduo não apenas viver melhor em sua vida privada (escapando da miséria por meio de um trabalho mais bemqualificado, por exemplo), mas também participar melhor da vida pública (a capacidade de receber informações para fortalecer sua atividade política, por exemplo); 4) Garantias de transparência: - Referem-se à necessidade dos sujeitos esperarem sinceridade na relação com outros sujeitos, instituições e com o próprio Estado. Além de essencial para a coesão social, ela pode ter papel importante na prevenção da corrupção, por exemplo; e, por fim, 5) Segurança protetora: - Resguarda os vulneráveis de caírem na miséria extrema por meio de uma rede de seguridade social e de outras medidas que visem às garantias mínimas 
de sobrevivência das pessoas. Esse conjunto oferece indicativos de que o desenvolvimento deve ter como referências valores que indiquem melhor qualidade de vida a todos os sujeitos de direito.

A concepção de desenvolvimento sustentável adotado na Constituição brasileira de 1988, e que está em conformidade com o Relatório Brundtland de 1987, conhecido como "Nosso futuro comum", indica que desenvolvimento é: "aquele que atende às necessidades do presente sem comprometer a possibilidade de as gerações futuras atenderem às suas próprias necessidades" (PÁDUA, 2009). Há um alcance desse conceito que deve estender-se sobre todas as decisões que envolvem as questões ambientais. A perspectiva jurídica é de consolidar uma relação harmoniosa dos seres humanos com a natureza, em todos os aspectos: ecológico, ambiental, social, político, econômico, demográfico, cultural, institucional e espacial. Ou seja, uma relação de ampliação das liberdades construída em uma perspectiva de respeito à natureza.

Ao se tratar da judicialização dos conflitos ambientais, há que se considerar que as demandas, em regra, partem de um conflito entre desenvolvimento econômico e cuidado com a natureza. Há a preexistência de um conflito, nesse caso ambiental, que dá início ao processo judicial, para a demanda apresentada ao Estado. O que se espera é que as respostas sejam produzidas no sentido de atender a uma concepção de desenvolvimento sustentável em cada situação fática. É o caso sob judice que permitirá a aplicação dos preceitos teóricos que vislumbrem a sustentabilidade. Afirmase que as respostas precisam considerar uma análise interdisciplinar, tendência que permite a "incorporação de aspectos sociológicos e antropológicos à forte tendência de se encarar sustentabilidade através de procedimentos técnicos, combinada com análises econômicas." (SILVA JUNIOR e FERREIRA, 2013, p. 8).

Uma saída para a compreensão dessa perspectiva de desenvolvimento sustentável é reconhecer que a natureza pode ser detentora de direitos. Rachel Carson (1962), no texto Primavera Silenciosa, já afirmava que é necessário chegar a um acordo com a natureza. Para ela, a humanidade foi desafiada a provar o domínio não da natureza, mas do controle que os seres humanos devem ter ao conviver com os demais seres vivos. Esse fundamento ainda é um desafio para o ordenamento jurídico.

A modernidade pretende resolver o reconhecimento de uma relação harmoniosa com a natureza, ao buscar racionalizar todas as relações. "São poucos os que enxergam corretamente que o reducionismo 
antropocêntrico foi reforçado na modernidade, porque os indivíduos tornaram-se sujeitos de direito ao serem considerados todos relativamente iguais, sendo impossível, então, atribuir o mesmo direito àqueles que, evidentemente, não são "tão" iguais a nós" (LEIS, 1999, p. 214). Ou seja, há o reconhecimento prioritário do domínio dos seres humanos sobre os demais. E o autor continua "[o] aumento da separação com o mundo natural dá-se, por consequência, porque a modernidade tende a obscurecer (ou assumir como transgressão) qualquer relação não racional entre os seres humanos" (LEIS, 1999, p. 214). Essa visão, além de reducionista, tem produzido consequências danosas na relação dos seres humanos com o meio ambiente. O debate, portanto, sobre um direito da natureza, é central para a construção dos fundamentos do desenvolvimento sustentável. Como já foi demonstrado, as normas jurídicas brasileiras estão alicerçadas em premissas que permitem avançar para uma perspectiva de justiça que busca a harmonia entre seres humanos e natureza.

\section{O FENÔMENO DA JUDICIALIZAÇÃO DOS CONFLITOS AMBIENTAIS COMO UMA DAS ESTRATÉGIAS PARA DAR VISIBILIDADE À CRISE SOCIOAMBIENTAL NAS DEMOCRACIAS MODERNAS}

Como já afirmado, o fenômeno da judicialização das relações sociais revela uma das formas de resolução dos conflitos na modernidade, que tem no Poder Judiciário uma das instituições legitimadas para responder aos conflitos decorrentes das demandas sociais. A judicialização acontece quando um conflito não é resolvido entre as partes interessadas e o Estado, através do Poder Judiciário, é chamado para resolvê-lo. As demandas podem ter interesses individuais ou coletivos e a decisão alcança somente os demandatários. A decisão não tem o alcance para generalização. No caso dos conflitos ambientais, o fenômeno da judicialização tem servido especialmente para dar visibilidade aos conflitos, apresentar socialmente situações em que a legislação não é cumprida, ou, no limite, - quando há divergências sobre a interpretação ou os procedimentos de aplicação das leis -, revelar a defesa de direitos que podem ser formalmente assegurados mas, carecem de eficácia. Outro aspecto que a judicialização tem possibilitado é a construção e afirmação de determinados conceitos, revelando as perspectivas teóricas dos integrantes do Poder Judiciário. No caso do presente estudo, é importante identificar como têm sido as decisões 
que envolvem os conflitos ambientais nos aspectos do desenvolvimento sustentável e da relação estabelecida entre seres humanos e a natureza, especialmente porque se entende que essas são questões centrais no tratamento dos conflitos ambientais.

Com a intensificação do fenômeno da judicialização das relações sociais, o Poder Judiciário assume um papel de protagonista, porque o 'juiz' passa a dizer o direito e assume a condição de um garantidor das promessas da democracia moderna (GARAPON, 2001). O que se espera em sociedades democráticas e organizadas a partir dos poderes legitimamente estabelecidos é que a ordem jurídica seja assegurada. A constante busca pelo Poder Judiciário, se, por um lado, revela a possibilidade de reivindicação dos direitos, por outro, revela que direitos formalmente assegurados acabam por não ser efetivados. Como já afirmado, o fenômeno da judicialização leva à individualização dos conflitos, ou seja, à produção de respostas somente aos sujeitos envolvidos na demanda. No caso dos conflitos ambientais, ainda que as demandas sejam de interesse coletivo e que envolvam uma pluralidade de sujeitos - muitas vezes, comunidades inteiras -, as respostas são para o caso, para a demanda específica. É importante evidenciar que esse fenômeno da judicialização pode, portanto, ser analisado pelo viés das contribuições que apresenta para a democracia moderna, mas pode ser indicador das limitações desse modelo de organização da vida em sociedade. Neste artigo, especificamente, o que se pretende é identificar como esse fenômeno pode contribuir para fortalecer ou definir perspectivas do conceito de desenvolvimento sustentável e como os tribunais têm se manifestado no entendimento da relação seres humanos e direitos da natureza quando decidem sobre o desenvolvimento.

Uma tarefa para a análise é entender como o Poder Judiciário se apresenta com essas atribuições. O Poder Judiciário possui legitimamente o poder de guardião dos direitos, com duas funções previstas na Constituição do Brasil de 1988: uma, de poder de Estado e outra, de instituição prestadora de serviços (SADEK, 2004a, p. 79). A função desse poder "não é apenas limitar o poder absoluto e assegurar direitos, mas ser um instrumento para a realização da justiça social e para a promoção de direitos, incorporando valores da igualdade social, econômica e cultural." (SADEK, 2004a, p. 79). Muito embora o modelo jurídico e político do Estado Democrático de Direitos no Brasil amplie o espaço do Poder Legislativo, assim como o da responsabilidade de fiscalização do Poder Executivo, inclusive permitindo a esse poder legislar por meio de medidas provisória, "essas 
potencialidades aumentaram a responsabilidade do Judiciário de exercer a mediação política entre os dois outros poderes e no controle constitucional dos atos legislativos e de governo" (SADEK, 2004, 80). O que se está afirmando é que o modelo de democracia do Brasil atribui ao Poder Judiciário esse papel de protagonismo, "representando uma mudança substancial no perfil do Poder Judiciário, alçando-o para o centro da vida pública e conferindo-lhe um papel de protagonista de primeira grandeza" (SADEK, 2004a, p. 81). Segundo Boaventura de Souza Santos (2005, p. 97), "[e]ste novo protagonismo judiciário traduz-se num confronto com a classe política e com outros órgãos de soberania, nomeadamente o poder executivo. Estamos perante uma judicialização dos conflitos políticos que não pode deixar de traduzir-se na politização dos conflitos judiciários". A reflexão do autor aponta, portanto, para um dos riscos do fenômeno da judicialização, que é o da politização das decisões judiciais ou da judicialização da política. São consequências que a realidade brasileira tem evidenciado nas decisões judiciais que envolveram, por exemplo, o Processo de Impedimento da Presidente Dilma Roussef, em 2016. Muitos dos posicionamentos da Suprema Corte brasileira foram mais políticos do que firmados nos preceitos legais que envolviam as questões em debate no caso específico, ainda que muitos juristas afirmem sobre a legalidade do processo. O ministro Barroso $^{1}$ (2017) afirma que há 30 anos de estabilidade das instituições e que o processo de 2016 indica a manutenção dessa estabilidade. Tudo ocorreu, segundo ele, dentro dos procedimentos estabelecidos na Constituição Federal de 1988.

Apesar dessas limitações decorrentes das relações de poder e de interesses em jogo no fenômeno da judicialização, neste estudo, é adequado reafirmar uma compreensão do fenômeno jurídico produzido na modernidade, que recorre, de maneira sistemática, ao conceito de racionalidade (WEBER, 1999), no qual a judicialização é tomada como uma forma legitima de resolução dos conflitos. No estudo do direito, na obra Economia e Sociedade, ao tratar sobre a relação de produção de "reglas y formas fijas" como sendo a forma de estabelecer os instrumentos de controle do poder, o autor afirma que o direito é uma forma de limitação do poder de dominação e, ao mesmo tempo, instrumento de divisão do poder (WEBER, 1999, p.506). Afirma, ainda, que: “[s]ólo el Occidente ha

1 Palestra proferida pelo Ministro Luís Roberto Barroso em Evento: Repensando o Brasil: ideias para um novo país, no dia 1 de dezembro de 2017, às 20h. Auditório da OAB/SC.

http://www.oab-sc.com.br/noticias/oabsc-traz-florianopolis-ministro-do-stf-luis-robertobarroso/14760 
elaborado una doctrina científica del derecho público, porque únicamente en él ha asumido la asociación política el carácter de un instituto con división racional de poderes y competencias" (WEBER, 1999, p. 507). A divisão do poder é racional; assim, espera-se que o fenômeno da judicialização também possa balizar-se nos fundamentos dessa produção racional da ordem jurídica. Formalmente, esse é o modelo de ordem jurídica que se apresenta para a atuação dos magistrados, portanto, também, com mecanismos de controle e consequente garantia do direito.

A análise do fenômeno da judicialização, como processo de produção de uma ordem social, provém de uma construção teórica que entende o sistema jurídico como um sistema completo que pode, a partir da racionalidade, produzir regras gerais, abstratas e impessoais, que organizam a vida dos sujeitos, garantindo uma convivência harmônica e a mais próxima possível dos valores de justiça que cada tempo apresenta. Weber (1999) indica alguns caminhos que podem fundamentar essas concepções de produção de uma ordem jurídica racional: 1) toda a decisão jurídica é a aplicação de um conceito abstrato para um caso concreto; 2) pela lógica jurídica, é possível encontrar uma solução para o caso concreto que se apoie em conceitos abstratos em vigor; 3) o sistema jurídico vigente é um sistema sem lacunas; 4) casos que não podem ser resolvidos racionalmente não são importantes para o Direito e 5) a conduta dos homens é a aplicação ou execução dos preceitos jurídicos ou se constitui como infração desses preceitos. Esses fundamentos indicam que o ponto de partida do Direito na modernidade constitui, apesar da complexidade, os mesmos pontos de referência no período já indicado pelas suas especificidades como pós-modernidade. Essa racionalidade deve dialogar com as fragilidades de uma racionalidade instrumental e, portanto, limitada, mas que pode ter na atuação da magistratura um mecanismo de atuação de instituições democráticas e legítimas. Muitos são os aspectos que indicam as limitações dessa perspectiva, inclusive pelas lacunas que podem ser indicadas nas relações que estabelecem os contornos do Estado brasileiro. Essas limitações não impedem que o fenômeno da judicialização seja um dado relevante no contexto das relações sociais e políticas no Brasil. Analisálas é, em certa medida, evidenciar essas limitações: qual ordem jurídica? Produzida por quem? Quem são os operadores jurídicos que tratam dessas relações? Como tratam? Quais os interesses que representam?

Ainda no sentido de identificar, teoricamente, como o fenômeno da judicialização pode atualizar o direito e produzir novas regras que 
incorporem a defesa de um novo modelo de desenvolvimento sustentável na área ambiental, recorre-se à reflexão de Weber (1999, p. 518):

\footnotetext{
"puede tratarse de la revelación de una decisión individual sobre lo en determinado caso concreto es justo, (...) la inspiración de nuevas normas puede venir al personaje carismáticamente calificado con independência, real o aparente, de una determinada ocasión concreta, es decir, sin que en las condiciones exteriores se dé modificación alguna".
}

Ou seja, as demandas podem fazer o juiz, a partir do caso concreto, reafirmar interpretações e produzir respostas que interferem na criação de novas normas jurídicas, ou, ainda, reafirmar determinados conceitos jurídicos. Na perspectiva weberiana adequada ao modelo de Estado Moderno, há autoridade no Poder Judiciário para essa produção.

Nesse sentido, Weber (1999, p. 531) afirma:

\begin{abstract}
un derecho puede ser racionalizado en diversas formas, y no necesariamente en la direción que implica el desplegamiento de sus cualidades propriamente ‘jurídicas'. Pero la direción en que estas cualidades formales se desenvuelven encuéntrase condicionada directamente por circunstancias que podríamos llamar 'intrajurídicas', a saber, la peculiaridad del círculo de personas que pueden influir profesionalmente en la formación del derecho y solo indirectamente por las condicones económicas y racionales de índole general. En primer término figura el tipo de la 'doctrina jurídica', expresión que aquí significa educación o formación escolar de los juristas prácticos.
\end{abstract}

O reconhecimento desse lugar de produção da ordem jurídica pode apresentar como desafio para o estudo pensar quem são esses juristas técnicos, como são formados e quais as perspectivas jurídicas com as quais trabalham. Nesse aspecto, entende-se que o fenômeno da judicialização das democracias modernas, especialmente na experiência brasileira, tem revelado uma magistratura legalista. No caso do Direito Ambiental, o texto constitucional brasileiro pode permitir interpretações que ampliam e definem uma maior proteção ao ambiente e a busca da garantia de um ambiente equilibrado para as presentes e as futuras gerações, o que é possível num contexto de desenvolvimento sustentável. $\mathrm{O}$ apego à lei, porém, leva parcelas significativas de decisões a retardar a prestação jurisdicional: "sufocadas pela desordem de mandamentos legais, de recursos, instrumentos e expedientes formais a serem cumpridos 
pela burocracia estatal" (BITTAR, 2009, 443). Os aspectos negativos, nesse caso, estão relacionados com a formalização e a manutenção de um positivismo dogmático.

A importância que o Poder Judiciário passa a ocupar nesse fenômeno justifica reconhecer as críticas que existem sobre a atuação desse poder no Brasil. Como afirma Tereza Sadek (2004a, p.85),

\footnotetext{
"são frequentes as críticas segundo as quais vive-se em um "manicômio jurídico"; a magistratura age "ideológica e irresponsavelmente", como se os recursos públicos fossem inesgotáveis, ou alheia às consequências de suas decisões na economia ou na máquina administrativa; juízes julgam-se os "verdadeiros representantes do interesse do povo".
}

Ou ainda, "em um país com uma ampla agenda de reformas e que adote um modelo institucional que combina a judicialização da política e a politização do Judiciário, como é o caso do Brasil, os problemas oriundos da dimensão política do Poder Judiciário são mais do que esperados; tornam-se inevitáveis" (SADEK, 2004b, p. 8).

Nesse aspecto, a produção da ordem jurídica pelo Poder Legislativo apresenta, no primeiro momento, um poder que teria maior legitimidade, eleito pelo povo, com a representatividade que a democracia exige e, acima de tudo, com o alcance da generalidade. As decisões caso a caso como são as produzidas pelo Poder Judiciário, além do alcance imediato, de império de lei entre as partes, têm o aspecto da pessoalidade, da situação particular que pode ser geradora de pequenas ou grandes 'injustiças'.

A tomada de decisão, por outro lado, pode ser um recurso para denunciar os limites do alcance formal da lei. Dá-se ao caso a visibilidade das consequências, em determinadas situações, da distância entre o que prescreve a norma jurídica e a realidade das relações sociais. Aqui, o Poder Judiciário é

\footnotetext{
"chamado a descobrir o direito do caso concreto, não simplesmente por meio da formal subsunção do fato à norma, mas mediante valorações e a adaptação da norma à dinâmica da realidade social. Nesse sentido, o juiz fortemente vinculado à lei é substituído por um juiz modelador da vida social, com sensibilidade para captar e atender as múltiplas necessidades sociais” (VERBICARO, 2008, p. 395).
}

Veredas do Direito, Belo Horizonte, $\cdot$ v.15 $\cdot$ n.33 $\cdot$ p.209-242 $\cdot$ Setembro/Dezembro de 2018 
Há, portanto, uma afirmação que espera do Poder Judiciário a exteriorização de um modelo de justiça, de bem comum que está presente na ordem jurídica e que o fenômeno da judicialização pode externar.

Um elemento que auxilia nessa reflexão é a percepção de que há um lugar de poder para dizer o direito ou de que uma "relação de autoridade entre o que manda e o que obedece não se assenta nem na razão comum nem no poder que manda; o que eles possuem em comum é a própria hierarquia, cujo direito e legitimidade ambos reconhecem e na qual ambos têm lugar estável predeterminado" (ARENDT, 2011, p. 129). Há o reconhecimento pela existência do poder e da autoridade e a aceitação destes na formação das relações sociais. O direito é o instrumento que permite relacionar o poder e a dominação. Essa equação aparece na autoridade que é representada pelos juízes nos processos de judicialização dos conflitos ambientais.

Os magistrados passam a ocupar um lugar na produção do direito que permite falar menos em 'racionalização' ou 'regulação' e mais em 'civilização' ou 'humanidade'. "A justiça surge, então, como um meio simbólico de pacificar, de eliminar o conflito" (ALLARD e GARAPON, 2006, p. 39).

\footnotetext{
O poder dos juízes advém de duas funções que constituem o fazer dos magistrados que é o "imperium, isto é, o poder de impor uma solução às partes" e "a jurisdictio, isto é, a capacidade de dizer o direito, os fundamentos" ou seja, o imperium está relacionado com o poder que os magistrados possuem, e a jurisdictio está relacionada com a necessidade de convencer de que a decisão foi a correta. É a relação de poder e autoridade presentes no exercício das funções dos magistrados (ALLARD e GARAPON, 2006, p. 44).
}

Todas as decisões proferidas pelos magistrados devem alcançar esse status de poder e convencimento. De reconhecimento de que foi uma decisão acertada. É formalmente a busca por uma decisão racional, ou seja, de um juiz que tem a preocupação com a imparcialidade. Para Ricoeur (2008, p.9) "a instituição se encarna na personagem do juiz, que, colocado como terceiro entre as partes no processo, desempenha o papel de terceiro em segundo grau; ele é o operador da justa distância que o processo institui entre as partes". O autor revela a importância que o magistrado passa a ocupar, pois o "juiz está para o jurídico assim como o mestre de justiça está para a moral e para o príncipe, ou como qualquer outra figura 
personalizada do poder soberano está para a política. Mas, é apenas na figura do juiz que a justiça se dá a reconhecer como 'primeira virtude das instituições sociais" (RICOEUR, 2008, p. 9). É o fazer justiça do caso concreto, "do aqui e agora". A decisão proferida pelo juiz tem um papel de pôr fim às incertezas. Atribui ao conflito uma decisão final. Ou seja, tem o papel de revelar que os poderes formalmente constituídos têm lugar e ocupam a defesa quase que sistemática de alguns interesses bem definidos, nesse caso, de parcelas da sociedade que sustentam as presentes relações de poder.

Na perspectiva de produção da ordem jurídica, outro limite que aparece para a judicialização dos conflitos sociais é a diversidade dos membros que compõem esse poder. Sadek (2004a, p. 89) afirma que

"quanto à mentalidade, o Judiciário não difere de outras instituições igualmente fechadas, com traços aristocráticos. O figurino da instituição tem se mostrado um ponto problemático, uma vez que, longe de encorajar o substantivo, prende-se à forma; em vez de premiar o compromisso com o real, incentiva o saber abstrato. (...) Sublinhe-se, contudo, que nos últimos anos têm crescido as reações internas a esse modelo. Tanto assim que, hoje, dificilmente, pode-se afirmar que a magistratura constitua um corpo homogêneo".

O texto da Maria Tereza Sadek $(2004 a, 89)$ aponta que

"muitos juízes têm se mostrado críticos da instituição e sensíveis a propostas de mudança, mesmo que afetem diretamente interesses corporativos e tradicionais. Ainda que esses grupos não sejam majoritários, constatam-se uma significativa renovação interna, no sentido de um maior pluralismo e uma consequente quebra no modelo de mentalidade tradicional".

Portanto, podem ser sujeitos que julgam sem o distanciamento que formalmente se espera ou pode interessar uma forma de julgar comprometida com as questões ambientais. Em qualquer das situações, encontram-se limites, porque o fenômeno da judicialização é a 'individualização' de conflitos. Consequentemente, as respostas diferenciadas são mais uma forma de complexificar essa forma de produção da ordem social.

Um dos maiores desafios da judicialização é a formação dos magistrados, que passam a ter a tarefa de dizer o direito para os conflitos ambientais que chegam até o Poder Judiciário. Além de o Direito Ambiental 
ser um ramo relativamente recente no sistema jurídico brasileiro, é um campo que exige uma formação multidisciplinar, que, além das questões de direito material e processual, envolve a temática ambiental e suas áreas afins. E, - talvez o mais complexo -, envolve, também, um conhecimento que permita identificar os interesses que estão em jogo quando se trata, por exemplo, de uma disputa entre desenvolvimento econômico sustentável e proteção aos 'bens naturais'. "Assim, o problema da expertise ultrapassa a questão da pura informação, porque inclui uma discussão sobre o que é aceitável, turvando a transparência dos laudos com interesses e valores díspares" (SILVA, 2009, p. 798).

Aliada a esse desafio da formação, encontra-se a percepção de que a judicialização dos conflitos sociais traz para o cenário do mundo jurídico uma maior participação de sujeitos que reivindicam seus direitos e defendem concepções específicas sobre o olhar que o direito deve realizar sobre cada caso em disputa (ROJO, 2004). São

\footnotetext{
"novas forças sociais representadas por importantes movimentos, organizações e grupos sociais que passaram a se mobilizar e a recorrer ao Poder Judiciário em busca do reconhecimento e da concretização dos seus direitos, o que demonstra a ampliação da participação política dos atores sociais e o engajamento da sociedade civil organizada, especialmente após a democratização do país” (VERBICARO, 2008, p. 400).
}

Aqui é possível identificar o surgimento de sujeitos que historicamente estiveram à margem do processo de produção dos pactos que constroem o Estado brasileiro e, mais do que isso, um olhar mais atento ao fenômeno da judicialização vai indicar os sujeitos da sociedade brasileira que continuam completamente excluídos de qualquer mecanismo de acesso ao uso das ferramentas que sustentam democracias, entre elas o acesso à possibilidade de reivindicar direitos.

Os sujeitos que passam a participar são impulsionados a agir, especialmente em decorrência de uma crise ambiental que repercute na vida, na cultura, na dinâmica política e social na escala mundial (MUNIZ, 2009). Ou, ainda,

a questão ambiental alcançou dimensão de problema global, mobilizando a sociedade civil organizada, os meios de comunicação e os governos de diversos países. Esse movimento trouxe um enfoque eminentemente sociológico para a questão ambiental, 
contribuindo para a discussão sobre os processos de constituição de conflitos entre grupos sociais no embate pelo uso dos recursos naturais, os chamados conflitos distributivos, ou simplesmente conflitos socioambientais (MUNIZ, 2009, p. 183).

A judicialização constitui uma das estratégias dos movimentos sociais envolvidos com as questões ambientais porque encontra nesse recurso uma forma de dar visibilidade aos conflitos (LOSEKANN, BISSOLI, 2017). No estudo do movimento ambientalista, evidencia-se que a judicialização nem sempre significa a busca pela vitória, mas uma forma de buscar a 'autoridade' que possa dizer o direito. Matthew M. Taylor e Luciano Da Ros (2008, p. 827) reconhecem que: "as táticas judiciais, em outras palavras, não estão necessariamente assentadas na expectativa de uma vitória judicial". Busca-se, muitas vezes, retardar, impedir, desmerecer ou declarar uma resposta esperada. A decisão judicial é, portanto, uma das estratégias. Nessa perspectiva, entende-se que

o Poder Judiciário não pode ser concebido como uma estrutura totalizadora e revolucionária capaz de provocar, por si só, transformações emancipadoras na sociedade e o desenvolvimento nacional do país. A via de acesso ao Judiciário é um importante canal e instrumento de veiculação de reivindicações individuais e coletivas, a fim de garantir os direitos fundamentais dos cidadãos, que não podem ser tratados como simples recomendações éticas ao Estado ou apêndices à democracia (VERBICARO, 2008, p. 404).

O último aspecto que precisa ser analisado sobre a judicialização é a importância que cada um dos poderes passa a ocupar no processo de consolidação da democracia no Brasil. Uma certa estabilidade das instituições é assegurada, à medida que se assegura a independência e a autonomia dos poderes, no modelo de vigência da Constituição Federal de 1988. O protagonismo do Poder Judiciário, apesar dos limites apontados até aqui, pode ser avaliado como o indicador de uma democracia que fortaleceu as suas bases nos anos de redemocratização do Estado brasileiro. Ainda:

atuação do Poder Judiciário propicia condições de possibilidade para uma dinamização à democracia, ao viabilizar a realização plena dos direitos fundamentais individuais e sociais. Com isso, impulsionam-se os poderes políticos do Estado a atuarem na realização efetiva de políticas públicas capazes de melhorar socialmente a vida da sociedade, a fim de resgatar a representatividade dos poderes políticos e a 
sua importância na condução do Estado e das políticas governamentais de inclusão e justiça social" (VERBICARO, 2008, p. 404).

A busca pelo Poder Judiciário pode ser um indicativo de exercício da cidadania, representado por um sentimento de pertencimento. Tanto os indivíduos como os diferentes grupos sociais reivindicam seus direitos porque se percebem detentores desses direitos. Rojo (2004) diz que o pertencimento a uma comunidade e o reconhecimento de uma autoridade política introduz a questão da ordem política, o que inclui a noção do cidadão como um indivíduo com "direito a ter direitos" a uma mudança política e à formação de uma comunidade que reconhece possuir liberdade e igualdade. A democracia deve ampliar os espaços de igualdade, especialmente para a disputa dos direitos. E o Poder Judiciário tem se constituído nesse espaço de assegurar direitos. O“[...] Judiciário, antes um Poder periférico, encapsulado em uma lógica com pretensões autopoiéticas inacessíveis aos leigos, distante das preocupações públicas e dos atores sociais, se mostra uma instituição central à democracia brasileira, quer no que se refere à sua expressão propriamente política, quer no que diz respeito à sua intervenção no âmbito social" (VIANA [et al.], 1999, p. 9). Reafirma-se, aqui, a percepção de que essa análise atinge parcelas da sociedade brasileira. Reconhece-se que a construção do pacto que cria o Estado brasileiro é fortemente alicerçada em um processo de não reconhecimento de parcelas muito significativas da sociedade brasileira. Alguns desses sujeitos começam a aparecer como sujeitos de políticas que pretendem minimamente começar o resgate de uma dívida histórica.

$\mathrm{O}$ fortalecimento e a estabilidade formal das instituições em um Estado Democrático de Direito apresentam, portanto, desafios também para o Poder Judiciário. Há a necessidade de ocupação de um papel relacionado à tomada de posição em defesa dos direitos fundamentais. "Alguns desses direitos são intimamente relacionados à administração da justiça, como a igualdade perante a lei, acesso a um poder judicial imparcial e independente, proteção contra detenções arbitrárias e tortura, mecanismos de controle contra a corrupção" (AZEVEDO, 2005, p. 215). A judicialização dos conflitos sociais trata da garantia dos direitos, tanto os formalmente assegurados quanto aqueles que precisam de uma releitura ou serem incluídos na ordem social. 


\section{A JUDICIALIZAÇÃO DOS CONFLITOS AMBIENTAIS E A CONCEPÇÃO DE DESENVOLVIMENTO SUSTENTÁVEL NAS DECISÕES DO SUPREMO TRIBUNAL FEDERAL}

Diante do quadro de crises socioambientais, de catástrofes ambientais e do reconhecimento de que o Direito Ambiental é um direito que deve ser assegurado para todos como um direito fundamental, é que se busca analisar como o Poder Judiciário tem se posicionado e aplicado o princípio do desenvolvimento sustentável previsto na Constituição Federal de 1988. Importante destacar que existem, pelo menos, dois novos instrumentos legais para a propositura de ações com demandas ambientais: a Ação de Responsabilidade Civil e Criminal por danos ao meio ambiente e a Ação Civil Pública. Ambas podem ser propostas pelo Ministério Público. A segunda pode, ainda, ser movida pela União, pela Defensoria Pública dos Estados-membros ou demais representantes dos estados e municípios, por autarquias, pelas empresas públicas, fundações e sociedades de economia mista e, ainda, pelas associações com mais de um ano de existência e que incluam a proteção ao meio ambiente, ao consumidor e/ou patrimônio histórico e cultural entre suas finalidades. Tais dispositivos demonstram uma ordem jurídica que visa à proteção do ambiente e a uma abertura para a judicialização.

Apesar de tudo, permanece, em grande medida, a prevalência de uma visão antropocêntrica dos direitos ambientais. $\mathrm{O}$ fenômeno da judicialização pode evidenciar a necessidade do reconhecimento de um Direito da Natureza e da construção de um modelo de desenvolvimento sustentável que permita sua proteção. Ou seja, a intensificação do fenômeno da judicialização dos conflitos ambientais e o crescimento dos problemas nessa área têm levado a manifestações do Poder Judiciário.

Para fazer o levantamento de ações judiciais que tratam de conflitos ambientais e nas quais aparece a temática do desenvolvimento sustentável, fez-se uso da ferramenta de busca por jurisprudências no site do Supremo Tribunal Federal. O objeto neste texto não é a quantificação de ações, dados que estão disponíveis nos relatórios do Conselho Nacional de Justiça (CNJ, 2010), mas, a identificação de decisões emblemáticas no debate sobre desenvolvimento ambiental posteriores à Constituição Federal de 1988, que incluem o princípio do desenvolvimento sustentável e a proteção ambiental como normas a serem cumpridas. Na página do Supremo Tribunal Federal, na consulta de jurisprudência, usando dois 
filtros: 'desenvolvimento sustentável” e selecionando "acórdãos na íntegra", encontram-se 43 decisões, no dia 15/11/2017. O propósito é uma análise detalhada do posicionamento da Corte e, para isso, foram selecionados somente três acórdãos que são exemplificativos do entendimento de desenvolvimento sustentável que o Supremo Tribunal Federal tem produzido no período de vigência da atual Constituição Federal do Brasil: a primeira é a decisão proferida na Ação Direta de Inconstitucionalidade (ADIN)3540-12 uma discussão sobre a lei que institui o Código Florestal; a segunda decisão é proferida na Arguição de Descumprimento de Preceito Fundamental (ADPF) $101^{3}$ e trata da importação de pneus recicláveis para o Brasil; e a terceira é a decisão da ADIN $4983^{4}$, que regulamenta a vaquejada como prática desportiva e cultural no Estado do Ceará. As escolhas foram definidas após a análise do conceito de desenvolvimento sustentável que aparece nas demais decisões. É importante destacar, aqui, que nem todas as decisões encontradas pelo filtro da busca tratam da matéria sobre desenvolvimento sustentável, mas aparecem na busca realizada porque um dos Ministros do STF integrava uma Comissão de Desenvolvimento Sustentável e tal indicativo acompanhava o seu nome nas pautas do julgamento.

Na primeira decisão em análise, o conceito de desenvolvimento sustentável está relacionado à possibilidade de uso dos recursos naturais. Predomina uma visão antropocêntrica, pois reconhece a necessidade de áreas de preservação permanente como forma de preservação e conservação da biodiversidade, mas permite que, por lei, tais áreas possam ser utilizadas. A ADIN 3540-1 trata do pedido do Procurador Geral da República sobre a inconstitucionalidade da Emenda Constitucional 2.16667 de 2001, que alterava o Código Florestal vigente na época, Lei de 2001 e ADIN julgada em 2005. A emenda nas alterações propostas permite que

\footnotetext{
2 A primeira é a decisão proferida na ADIN 3540-1 com pedido liminar, ajuizada em 2001, pelo Procurador-Geral da República, que busca a Declaração de Inconstitucionalidade dos arts. $1^{\circ}$. da Emenda Constitucional no.2.166-67 de 2001, que altera os arts. $4^{\circ}$ caput e parágrafos $1^{\circ}$., $2^{\circ}, 3^{\circ}$., $4^{\circ}$., $5^{\circ}$., $6^{\circ}$. e $7^{\circ}$. da Lei $4771 / 65$ que institui o Código Florestal. A decisão foi proferida em 1 de setembro de 2005 .

3 A segunda decisão é na ADPF 101, com pedido de medida liminar, ajuizada pelo Presidente da República, com fundamento "nos arts. $102, \S 1^{\circ}$, e 103, da Constituição da República, e no artigo $2^{\circ}$, inc. I, da Lei n. 9.882, de [3.12.99], (...) a fim de evitar e reparar lesão a preceito fundamental resultante de ato do Poder Público, representado por decisões judiciais que violam o mandamento constitucional previsto no art. 225 da Constituição" da República, trata de inúmeras decisões que autorizam a importação de pneus recicláveis para o Brasil, contrariando decisões já proferidas, julgada 2009.

4 A terceira é a decisão da ADIN 4983 ajuizada pelo Procurador da República com pedido de medida cautelar para declarar a Inconstitucionalidade da Lei $\mathrm{n}^{\circ} 15.299$, de 8 de janeiro de 2013, do estado do Ceará, que regulamenta a vaquejada como prática desportiva e cultural, julgada em 2016.
} 
as áreas de preservação permanente possam ter sua vegetação alterada, que sejam utilizadas desde que haja uma autorização da administração pública. Pelo texto da legislação anterior, essa possibilidade só era permitida por previsão de lei, norma geral, abstrata e aprovada pelo Poder Legislativo. A inconstitucionalidade foi preliminarmente reconhecida, apresentada pelo procurador da república, fundamentada no risco do uso de uma área de preservação permanente para o extrativismo mineral, que seria autorizado em uma reunião do Conselho Nacional do Meio Ambiente. O impacto que tais ações promovem no meio ambiente são, em regra, irreparáveis. Segundo o procurador, o controle de autoridades locais sobre a questão traz mais vulnerabilidade à proteção ambiental do que se tais autorizações continuassem emanando do Poder Legislativo. Na análise de mérito, o relator, Ministro Celso de Mello, modifica a decisão liminarmente concedida, com o fundamento de que garantir um meio ambiente equilibrado é necessário, porque se trata de "direitos humanos, qualificados estes enquanto valores fundamentais indisponíveis, como prerrogativas impregnadas de uma natureza essencialmente inexaurível" (BRASIL, 2005, Acórdão na Integra, p. 13 e 14). Ao reconhecer o status de direitos humanos para o Direito Ambiental, reconhece também a necessidade de defesa do meio ambiente por força do seu caráter intergeracional e pelos compromissos internacionais nas questões ambientais assumidos pelo Brasil. No entanto, entende que não há lesão do direito em autorizar a administração pública a realizar concessões de uso em áreas de preservação permanente sustentada por dois argumentos principais: os danos causados devem ser reparados (caráter do poluidor pagador) e que tal dispositivo é claro na legislação vigente, priorizando, aqui, o desenvolvimento econômico; e o segundo argumento é o de que o reconhecimento da inconstitucionalidade dessa emenda constitucional causaria mais danos ao desenvolvimento econômico das diferentes regiões do Brasil. Invoca o ministro, aqui, a presunção de que a autoridade administrativa local é a que terá as melhores condições de avaliar o equilíbrio entre os princípios de desenvolvimento econômico e os princípios da proteção ecológica, pois tais princípios, segundo o relator, são expressos no texto constitucional e, portanto, devem ser assegurados.

$\mathrm{O}$ voto do presidente do STF, na época ministro Nelson Jobim, também foi por reformular a sua decisão preliminar, e o fundamento volta-se para o aspecto de que a concessão de uso das áreas permanentes deve ter autorização da Administração Pública, por definição 
da Constituição Federal, e afirma que: "a preservação do meio ambiente ecologicamente equilibrado não significa a sua estagnação; significa, sim, que os atos de sua exploração não serão aqueles permitidos na forma do Direito comum, mas sim, através de uma série de medidas de preservação" (BRASIL, 2005, Acórdão na Integra, p. 43 e 44). No mesmo sentido, ocorreram também os votos do ministro Eros Grau e da ministra Ellen Gracie.

O ministro Carlos Brito, o ministro Sepúlveda Pertence e o ministro Cesar Peluso questionam nos manifestos a decisão sobre os riscos de permitir que a autoridade administrativa autorize a supressão da vegetação em áreas de preservação permanente. No entanto, dos três ministros, somente o ministro Carlos Brito entendeu pela declaração de inconstitucionalidade da emenda constitucional e pelo referendo da decisão liminarmente concedida.

Apesar das discordâncias formais com a demanda proposta, o ministro Celso Mello afirma que as decisões proferidas, exceto a de Carlos Brito, são de "interesse econômico" e não de proteção ao meio ambiente. Para fundamentar o seu voto pela inconstitucionalidade da emenda constitucional em debate, afirma:

\footnotetext{
“[p]obre Mãe-Terra, pobres gerações presentes e futuras no que acabam de olvidar os parâmetros da Carta da República, os parâmetros voltados para a preservação tanto quanto possível do meio ambiente, à integridade do meio ambiente, ao respeito do meio ambiente, no que é indispensável ao bem-estar do próprio homem." (BRASIL, 2005, Acórdão na Integra, p. 65)
}

Indicando em seu voto que a decisão pela manutenção da vigência da Emenda Constitucional é, substancialmente, proteção à exploração econômica dos bens naturais.

A decisão da maioria dos membros do STF no julgamento da ADIN 3540-1 foi pela improcedência do pedido de inconstitucionalidade e o pronto restabelecimento da vigência da lei.

No segundo caso, ADPF 101, julgada em 2009, tem-se o pedido do Presidente da República para a uniformização do entendimento sobre a importação de pneus usados pelo Brasil. O pedido é contra inúmeras decisões judiciais que permitem a importação de pneus usados apesar da legislação vigente que proíbe tal prática ${ }^{5}$. $\mathrm{Na}$ ação, reconhece-se a

5 Portaria DECEX no. 08/1991, do Departamento de Comércio Exterior; pela Convenção da 
exceção da legislação para os países do Mercosul, decorrente da decisão de laudo arbitral proferido pelo Tribunal Arbitral do Mercossul - a pedido do Uruguai e regulamentada internamente. $\mathrm{Na}$ inicial, ficam elencados os motivos do presidente, que justifica que tais decisões ferem os dispositivos já citados, dispositivos constitucionais vigentes e acordos internacionais em vigor e, principalmente, porque causam danos ambientais e ferem o direito à saúde da população brasileira. A relatora dessa matéria, ministra Cármem Lúcia, em seu longo voto, reconhece os danos que tais práticas causam. Reconhece, portanto, o dever do Estado brasileiro com a proteção do meio ambiente para as presentes e futuras gerações e, em relação à livre iniciativa que é usada com um dos argumentos da defesa, invoca o princípio do desenvolvimento sustentável como fundamento para afirmar que existem limites econômicos quando se trata de questões ambientais e que a proteção da vida e a garantia de um meio ambiente equilibrado precisam se sobrepor ao desenvolvimento econômico nessas situações. Afirma expressamente: "Assim, pelo risco de dano ao meio ambiente ou à saúde pública, tem aplicação plena o princípio constitucional da precaução ambiental, garantindo-se a supremacia do interesse público sobre o particular, na proteção da vida como bem maior à qual a Constituição deu especial atenção" (BRASIL, 2009, Acórdão na Íntegra, p. 119).

Um indicativo da complexidade dessa decisão e do impacto que ela produz, porque aponta um viés de desenvolvimento mais voltado para um equilíbrio entre desenvolvimento econômico e desenvolvimento sustentável, é o fato de que somente o voto da relatora com os anexos perfazem 179 páginas. $\mathrm{O}$ acórdão, com todos os votos, contém 278 páginas. O voto do ministro Menezes Direito acompanha o voto da relatora pela procedência da ação e destaca a "preservação do meio ambiente na sua conotação de bem da humanidade" (BRASIL, 2009, Acórdão na Íntegra, p. 195), ainda meio ambiente como bem, mas como um bem a ser preservado. O ministro Ricardo Lewandowski também acompanhou o voto da relatora. O Ministro Marco Aurélio em seu voto fundamenta as questões apontadas pela improcedência do pedido.

Os ministros Eros Grau, Gilmar Mendes, Ellen Gracie e Joaquim Barbosa votam acompanhando a decisão da relatora. Há no acórdão um debate sobre a decisão de deferimento parcial da arguição, porque a

Basileia sobre o Controle de Movimentos Transfronteiriços de Resíduos Perigosos e seu Depósito, de 22/03/1989; Pelas Resoluções 23/1996, 235/1998 e e258//1999 do Conselho Nacional do Meio Ambiente; pela Portaria SECEX 08/2000 da Secretaria de Comércio Exterior e Decreto 3919/2001 além dos compromissos com meio ambiente assumidos pelo Estado brasileiro 
ministra Cármem Lúcia, em seu voto, faz ressalvas para garantir os casos de importação já definidos em juízo, com trânsito julgado e já executados. Em relação aos demais casos essa decisão produzirá efeitos. É uma compreensão que reafirma os fundamentos constitucionais que protegem uma perspectiva de desenvolvimento sustentável e de proteção do meio ambiente para as presentes e futuras gerações.

O terceiro caso é a ADIN 4983, ajuizada pelo Procurador da República com pedido de medida cautelar para declarar a inconstitucionalidade da Lei $\mathrm{n}^{\circ} 15.299$, de 8 de janeiro de 2013, do estado do Ceará, que define a vaquejada como patrimônio cultural, julgada em 2016. Essa é a decisão que traz nos seus votos um posicionamento que busca estar em sintonia com um novo paradigma de Direito Ambiental e evidencia a necessidade de uma nova relação dos seres humanos com a natureza.

O Ministro Marco Aurélio, relator, julgou procedente o pedido, entendendo que é inconstitucional a lei que autoriza a vaquejada no estado do Ceará. Não reconhece o direito de submeter os animais a tratamento cruel, e que não há que se reconhecer nessa prática um patrimônio cultural. Os ministros Edson Fachin e Gilmar Mendes julgaram pela improcedência do pedido, reconhecendo a constitucionalidade da lei estadual.

A decisão do ministro Roberto Barroso pela inconstitucionalidade da lei fundamenta-se em uma perspectiva de respeito e de proteção aos direitos dos animais, pois parte da análise da vaquejada, da descrição do "esporte" e da necessária queda do boi e seu levantamento pelo rabo, o que, por estudos, comprovadamente causa danos ao animal. Não é admissível tal prática porque se fundamenta em uma relação dos seres humanos com os animais em uma perspectiva de "dominação, controle e exploração" (Brasil, 2016, Íntegra do Acórdão, p. 35). Barroso, em seu voto, resgata a construção histórica de correntes que defendem os direitos dos animais, que os reconhecem como 'sujeitos de uma vida', identifica que esta é a perspectiva constitucional brasileira, ao determinar que é dever do Estado proteger o ambiente para as presentes e futuras gerações. A ministra Rosa Weber e o ministro Celso de Mello acompanharam o voto do relator, no sentido da inconstitucionalidade da Lei. Os ministros Teori Zavascki, Luiz Fux e Dias Toffoli votaram pela constitucionalidade da lei. Com essas manifestações é, por maioria, declarada a inconstitucionalidade da Lei ${ }^{\circ}$ 15.299/2013, do estado do Ceará. 
As manifestações das cortes superiores são importantes para o fortalecimento de concepções que possam trazer a confirmação da necessidade do estabelecimento de uma nova relação dos seres humanos com a natureza como condição para o enfrentamento desse tempo de crise socioambiental. Outro caso que demonstra como o STF tem respondido sobre as questões que envolvem o meio ambiente e a garantia de um desenvolvimento sustentável é o julgamento da ADIN 3470 que, finalmente, por maioria, declarou a inconstitucionalidade do art. $2^{\circ}$ da Lei 9.055/95, com efeito vinculante e erga omnes ${ }^{6}$. A ADIN 3470, a ADIN 3937 e a ADIN 4066 são algumas das ações que tratavam da inconstitucionalidade da permissão do uso do amianto no Brasil, nos termos do art. 2 da Lei 9.055/95. Sobre essa temática, far-se-á, exclusivamente, a análise do voto do ministro Celso de Mello, da ADIN 4066, julgamento do dia 24/08/2017, no qual ele resgata a necessidade de decisões que asseguram os direitos inscritos na Constituição de 1988, de um meio ambiente equilibrado para as presentes e futuras gerações. Afirma o ministro Celso de Mello que as decisões que envolvem o Direito Ambiental visam "não só proteger o meio ambiente, mas, também, amparar a preservação da saúde e da vida das pessoas". (BRASIL, 2017, Voto Ministro Celso de Mello, p. 30) O ministro continua indicando a necessidade de um:

novo paradigma que emerge da constatação de que a evolução científica traz consigo riscos imprevisíveis, os quais estão a exigir uma reformulação das práticas e procedimentos tradicionalmente adotados nesse campo. Isso porque, como registra Cristiane Derani, é preciso 'considerar não só o risco de determinada atividade, como também os riscos futuros decorrentes de empreendimentos humanos, os quais nossa compreensão e o atual estágio de desenvolvimento da ciência jamais conseguem captar em toda densidade'(BRASIL, 2017, Voto Ministro Celso de Mello, p. 30).

A discussão desse tema envolve a necessidade de impedir a continuidade do uso do amianto pelos danos à saúde e, consequentemente, ao meio ambiente, que já estão comprovados. $\mathrm{O}$ voto menciona, ainda, que a proibição do uso desse material já ocorre em mais de 50 países e que o Brasil, além de prever em sua constituição o princípio básico de promover um desenvolvimento sustentável, é signatário de tratados que visam ao 6 Latim: contra todos, a respeito de todos ou em relação a todos. 
desenvolvimento sustentável como premissa básica para a sobrevivência de todos os seres vivos.

Ainda para ilustrar as implicações do fenômeno da judicilização e seus impactos nas relações sociais, pode ser citado o voto vencido proferido na Corte Internacional de Justiça sobre o caso do projeto Gabcikovo-Nagymaros, voto proferido pelo vice-presidente da corte, o juiz Christopher Gregory Weeramantry, julgado em 1997, no qual ele invoca a necessidade de consolidação de uma perspectiva de desenvolvimento sustentável como condição para proteger o meio ambiente para as futuras gerações (COUR INTERNATIONALE DE JUSTICE, 1997). No voto, Weeramanty chama atenção para as relações que os povos primitivos estabeleciam com a natureza e que eram relações de respeito, de cuidado de preservação, os únicos valores que poderão fazer com que a natureza seja assegurada para as gerações futuras. A relação de uso e predatória inviabiliza a sobrevivência de qualquer vida no planeta terra.

Por fim, o fenômeno de judicialização tem apontado um recurso que surge como alternativa na América Latina, um reconhecimento de que a natureza é detentora de Direitos. Há uma diversidade de ações em que a própria natureza passa a reivindicar seus direitos. Além de ações que têm sido objeto de estudos na América Latina, podem ser citados dois casos no Brasil, como exemplo. O primeiro é a procedência de uma ação civil pública proposta pelo Ministério Público em desfavor de Damiani Agrícola LTDA., com base no Inquérito Civil nº 01337.00004/2016, na qual o Rio Gravataí, no Rio Grande do Sul, em decisão liminar, foi reconhecido como sujeito de direitos e, portanto, com direitos de reparação de preservação e de ressarcimento dos danos sofridos (BRASIL, TJRS, 2017). E o segundo é uma inicial encaminhada em 2017, na qual o Rio Doce, da conhecida e lamentável catástrofe de Mariana, MG, ingressa como sujeito de direitos, pleiteando as condições de proteção ambiental (BRASIL, TJMG, 2017).

É preciso ter sensibilidade para a construção desses novos olhares que poderão permitir a sobrevivência dos seres humanos e da natureza, ou inviabilizam-se condições da vida nos espaços que nos cercam. O desafio é avançar no estabelecimento de novos princípios de convivência, novos valores nos processos de produção e, especialmente, construir novos modelos de consumo, considerando todos os seres vivos como seres detentores de direitos. 


\section{CONCLUSÃO}

Evidencia-se que a perspectiva de um desenvolvimento sustentável exige uma nova concepção da relação seres humanos e natureza. A velha concepção antropocêntrica do Direito Ambiental aponta para uma noção de dominação e exploração da natureza e, portanto, inviável para a sobrevivência de todas as espécies no atual modelo de produção e de consumo.

O recurso da judicialização dos conflitos ambientais, além de um recurso estratégico para a publicização dos conflitos e a reivindicação de direitos sonegados, tem revelado as limitações do Direito na pósmodernidade. O que se tem é um direito formal, positivado, mas que se distancia de um processo mais efetivo de garantia dos direitos.

Outro aspecto que o estudo das decisões judiciais revela é de que as promessas de um possível direito justo, neutro e que poderia ser assegurado para todos em condições de igualdade, de liberdade e de oportunidades, é, na verdade, mais uma falácia da ordem jurídica do que a formalização das condições de garantia dos direitos. O que se tem são julgadores comprometidos com um modelo de desenvolvimento que tem a questão econômica como questão central. Essa perspectiva fica evidenciada na análise da ADIN 3540-1, na qual os ministros entendem que é necessário assegurar o modelo de desenvolvimento econômico, que autoriza a supressão da vegetação em áreas de preservação permanente, com autorização da administração pública, mas com elevado poder de discricionariedade, sem considerar o interesse da proteção ambiental.

Apesar da intensificação da judicialização como uma das formas de resolução dos conflitos ambientais, afirma-se que mudanças significativas somente serão alcançadas à medida que um maior número de sujeitos e instituições mobilizarem-se por mudanças no campo do Direito Ambiental. A máxima da Constituição de 1988 ainda é o desafio atual: é dever do Estado e da sociedade civil a ampliação de espaços para a construção de um modelo de desenvolvimento alicerçado sim, nos indicadores de desenvolvimento econômico sustentável apontados por Amartya Sen (2010), e que possam representar a diversidade, a pluralidade e a complexidade que constituem a sociedade brasileira e, principalmente, que esteja alicerçada em um novo modelo paradigmático da relação entre seres humanos e natureza. 


\section{REFERÊNCIAS}

ALLARD, Julie e GARAPON, Antoine. Os juizes na mundialização: a nova revolução do direito. Tradução Rogério Alves. Lisboa: Instituto Piaget, 2006.

ARENDT, Hannah. Entre o passado e o Futuro. $7^{\mathrm{a}}$. ed. Tradução Mauro W. Barbosa. São Paulo: Perspectiva, 2011.

AZEVEDO, Rodrigo Ghiringhelli de. Criminalidade e justiça penal na América Latina. Sociologias, Porto Alegre: UFRGS, Programa de Pós Graduação em Sociologia no.13, jan./jun2005, p.212-241.

BECK, U. Sociedade de Risco: rumo a uma outra modernidade. São Paulo: Editora 34, 2010.

BITTAR, Eduardo. Homem globalizado, com que direito? Eduardo Bittar from cpfl cultura on Vimeo. Disponível em: https://www.youtube.com/ watch?v=L74yuOdtWUI - Gravado em: 12/8/2004.

BITTAR, Eduardo. Carlos Bianca. $O$ direito na pós-modernidade e reflexões frankfurtianas. $2^{\text {a }}$. ed. rev., atual. e ampliada. Rio de Janeiro: Forense Universitária, 2009.

BRASIL. Supremo Tribunal Federal. ADIN 3540-1, julgado em 2005.

BRASIL. Supremo Tribunal Federal. ADPF 101, julgado em 2009.

BRASIL. Supremo Tribunal Federal. ADIN 4983, julgado em 2016.

BRASIL. Supremo Tribunal Federal. ADIN 4066, Voto Ministro Celso e Melo, julgado em 2017.

BRASIL. Tribunal de Justiça do Rio Grande do Sul. Inquérito Civil $\mathrm{n}^{\circ}$ 01337.00004/2016, decisão de 2017.

BRASIL. Tribunal de Justiça de Minas Gerais. Belo Horizonte, inicial Rio Doce - proposta por Lafayette Novaes, em 2017.

CARSON, Rachel. Primavera Silenciosa. 2. ed. São Paulo: Portico, 1962.

CONSELHO NACIONAL DE JUSTIÇA. Relatório do Conselho Nacional de Justiça, 2010. Disponível em: http://www.cnj.jus.br/publicacoes/ relatorios-publicacoes, Acesso em: 01/08/2017.

COUR INTERNATIONALE DE JUSTICE. Case Concerning The Gabcikovo-Nagymaros Project, voto do vice-presidente da Corte, o juiz Christopher Gregory Weeramantry, 1997.

DERANI, Cristiane. Direito ambiental econômico. São Paulo: Max Limonad, 1997. 
DERANI, Cristiane. Direito ambiental econômico. $3^{\mathrm{a}}$. Edição. São Paulo: Max Limonad, 2008.

GARAPON, Antoine. O juiz e a democracia: o guardião das promessas. Tradução: Maria Luiza de Carvalho. Rio de Janeiro: Revan, 2001.

HARVEY, David. Condição pós-moderna: uma pesquisa sobre as origens da mudança cultural. Tradução Adail Ubirajara Sobral e Maria Stela Gonçalves. 10. ed. Edições Loyola: São Paulo, 2001.

LEIS, Héctor Ricardo. A modernidade insustentável: as críticas do ambientalismo à sociedade contemporânea. Petrópolis, RJ: Vozes; Santa Catarina: UFSC, 1999.

LOSEKANN, Cristiana e BISSOLI, Luiza Duarte. Direito, Mobilização Social e Mudança Institucional. Revista Brasileira Ciências Sociais [online]. 2017, vol.32, n.94, e329403. Epub 15-Maio-2017. ISSN 18069053. Disponível em: http://dx.doi.org/10.17666/329403/2017.

MUNIZ, Lenir Moraes. Ecologia Política: o campo de estudo dos conflitos sócio-ambientais. Revista Pós Ciências Sociais, v.6, n.12, 2009, p. 181196.

PÁDUA, Josá Augusto (org). Desenvolvimento, Justiça e meio ambiente. Belo Horizonte: Editora UFMG; São Paulo: Peirópolis, 2009.

RICOEUR, Paul. Ojusto 1: a justiça como regra moral e como instituição. Tradução Ivone C. Benedetti. São Paulo: WMF Martins Fontes,2008.

ROJO, Raul Enrique. Por una sociologia jurídica del poder y la dominación. Sociologias.Porto Alegre: IFCH/UFRGS, ano 6, n 13, p. 36-81, jan/jun. 2005.

SANTOS, Boaventura de Sousa. Para uma sociologia das ausências e uma sociologia das emergências. Revista Crítica de Ciências Sociais, n. 63, p. 237-280, Out 2002.

SANTOS, Boaventura de Sousa. Os tribunais e as novas tecnologias de comunicação e informação. Sociologias.Porto Alegre: UFRGS, Programa de Pós Graduação em Sociologia, no. 13, jan./jun, p. 82-108. 2005.

SANTOS, Boaventura de Sousa. A dificil democracia: reinventar as esquerdas. São Paulo: Boitempo, 2016.

SEN, Amartya. Desenvolvimento como liberdade. Tradução: Laura teixeira Motta; revisão técnica: Ricardo Doninelli Mendes. São Paulo: Companhia das Letras, 2010.

SADEK, Maria Tereza. Judiciário: mudanças e reformas. Estudos Avançados, n. 18 (51), p 79 - 101. 2004a. 
SADEK, Maria Tereza. Poder Judiciário: Perspectivas de Reforma. Opinião Pública, Campinas, Vol. X, nº 1, Maio, p. 01-62. 2004b.

SILVA, Gláucia. Expertise e Participação da população em contexto de risco nuclear: democracia e licenciamento ambiental de Angra 3. DADOS - Revista de Ciências Sociais, Rio de Janeiro, Vol. 52, n. 3, 2009, p. 771 a 805 .

SILVA JÚNIOR, Roberto Donato, FERREIRA, Leila da Costa. Sustentabilidade na era das conferências sobre meio ambiente e desenvolvimento - um olhar para a ecologia e economia. Ambiente e Sociedade. São Paulo, v. XVI, número 1. p. 1-18. jan/mar, 2013.

TAYLOR, Matthew M. e DA ROS, Luciano. Os Partidos Dentro e Fora do Poder: A Judicialização como Resultado Contingente da Estratégia Política. DADOS - Revista de Ciências Sociais, Rio de Janeiro, Vol. 51, n. 4, , p. 825 - 864. 2008.

VERBICARO, Loiane Prado. Um estudo sobre as condições facilitadoras da judicialização da política no Brasil. Revista Direito GV, São Paulo 4(2), p. 389-406, jul/dez, 2008 .

VIANNA, Luiz Werneck[et al.]. A Judicialização da Política e das Relações Sociais no Brasil. Rio de Janeiro: Revan, 1999.

WEBER, Max.Economia y Sociedad.Esbozo de sociologia compreensiva. México: Fondo de Cultura Económica, 1999.

\section{Como citar este artigo (ABNT):}

BÖLTER, Serli Genz; DERANI, Cristiane. DIREITO AMBIENTAL E DESENVOLVIMENTO SUSTENTÁVEL: UMA ANÁLISE DA JUDICIALIZAÇÃO DAS RELAÇÕES SOCIAIS. Veredas do Direito, Belo Horizonte, v. 15, n. 33, p. 209-242, set./dez. 2018. Disponível em: $\quad<$ http://www.domhelder.edu.br/revista/index.php/veredas/article/ view/1242>. Acesso em: dia mês. ano.

Artigo recebido em: 02/08/2018 Artigo aceito em: 20/11/2018 